\title{
Occurrence of Organochlorine Pesticides in Stream Bed Sediment and Fish From Selected Streams on the Island of Oahu, Hawaii, 1998
}

By Anne M. Brasher and Stephen S. Anthony

Organochlorine pesticides were heavily used from the mid-1940s to the mid-1980s. The persistence of organochlorine pesticides, their tendency to accumulate in soil, sediment, and biota, and their harmful effects on wildlife brought this class of compounds into disfavor and eventually resulted in restriction or cancellation of most of them in the United States (Nowell and others, 1999). Despite use restrictions, these compounds continue to be detected in sediment and fish tissue samples.

This study was undertaken as part of the National Water-Quality Assessment (NAWQA) program of the U.S. Geological Survey (USGS). The NAWQA program assesses watersheds as integrated systems, focusing on chemical concentrations, physical conditions, and biological status in streams. One component of NAWQA is an occurrence survey of organic contaminants and trace elements in stream bed sediment and fish tissue.

The goal of the Oahu stream bed sediment and fish tissue occurrence survey was to determine which organochlorine contaminants are present in streams around the island, and with which land uses they are associated. An understanding of relations between land use and organochlorine compounds will allow land management practices to be designed to reduce the loading of contaminants to streams and nearshore waters.

\section{Study setting}

There are a total of 59 NAWQA study units across the Nation. The island of Oahu, which is one of eleven study units to begin investigations in 1997, is undergoing rapid population growth and associated land-use changes. Following the 100-year period (1890-1990) when plantation agriculture dominated central Oahu, there has been a decrease in agricultural acreage, conversion from single crop plantations to diversified agriculture, and an increase in suburban development.

The resident population of Oahu more than doubled from 1950 to 1994 , and Honolulu is now one of the 25 largest cities in the Nation. Urbanization affects water quality by changing land-cover characteristics from porous soil and vegetation to impervious pavement, which increases stormwater runoff to streams, and introduces contaminants associated with urban development.

One important aspect of urbanization in Hawaii is the need for termite control. The Formosan subterranean termite causes more than $\$ 100$ million in damage each year to wooden structures in Hawaii. Before 1980, organochlorine pesticides such as

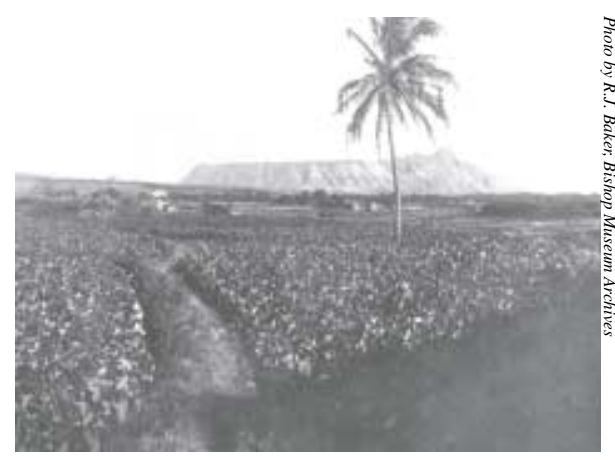

Honolulu 1910. aldrin, chlordane, and heptachlor were widely used for termite control. By 1988, they had largely been replaced by more acutely toxic but less persistent organophosphate compounds such as chlorpyrifos and carbamate pesticides (which are now also being phased out for urban use).

Alternative termite control methods are being developed to minimize the need for extensive use of pesticides around buildings. Alternative methods include physical barriers, wiremesh barriers, in-ground and aboveground baiting systems, removable building components, and construction materials resistant to termite damage.

\section{Sampling approach}

Stream bed sediment and fish samples were collected from six streams on the island of Oahu during the fall of 1998 to determine the occurrence of organochlorine pesticides. The six sites were selected on the basis of land-use type (table 1). The sites represent four environmental settings on Oahu: agricultural, urban, conservation (reference), and mixed (agricultural and urban) land use (fig. 1).

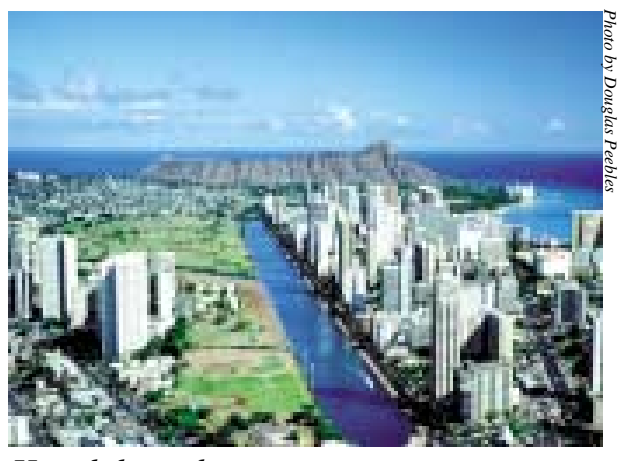

Honolulu today. 


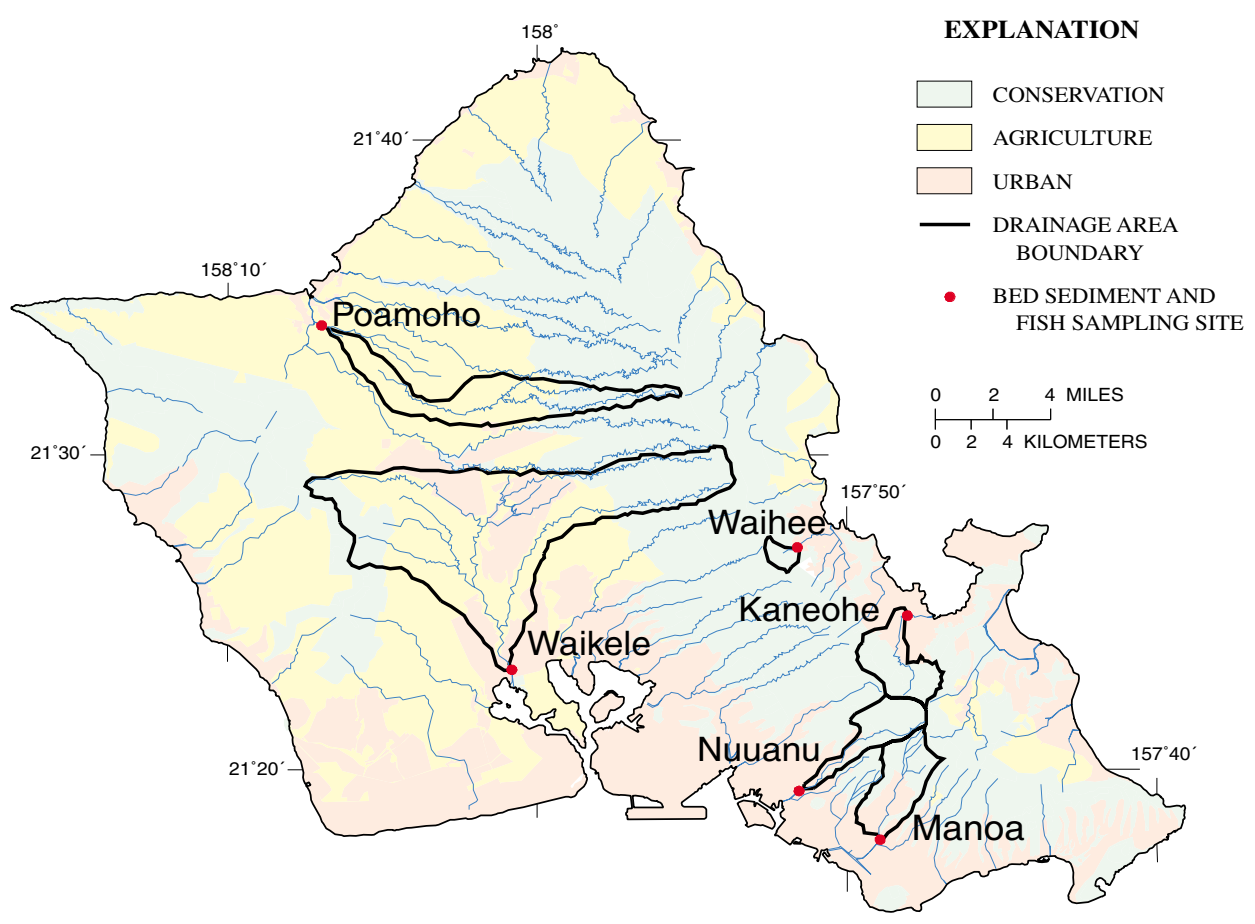

Figure 1. Sites where bed sediment and fish were sampled for organochlorine pesticides, 1998, Oahu.

Methods for collecting and processing sediment and biota followed nationally consistent procedures (Shelton and Capel, 1994; Crawford and Luoma, 1993), and all samples were analyzed at the USGS National Water Quality Laboratory in Arvada, Colorado. A total of 32 organochlorine compounds were analyzed in bed sediment. Twenty-eight organochlorine compounds were analyzed in fish tissue.

Sediment samples were collected from undisturbed depositional zones along a 100-meter reach at each stream. Sampling was confined to the upper 2 centimeters of bed sediment which reflects contaminants most recently contributed to the stream. Subsamples from along the reach were composited and wet-sieved in the field, using a 2-mm stainless steel sieve. Samples were then frozen and shipped to the laboratory for analysis.

Non-native (aquarium) fish were collected using an electrofisher, supplemented by seining as needed. Fish were measured, weighed, and examined for anomalies. Species selection was based on availability, with Poeciliidae (guppies and mollies) collected at five sites and Cichlidae (jewel cichlid) at one site (table 1). Whole fish were used for analysis and all fish collected at a site were composited to form a single sample of

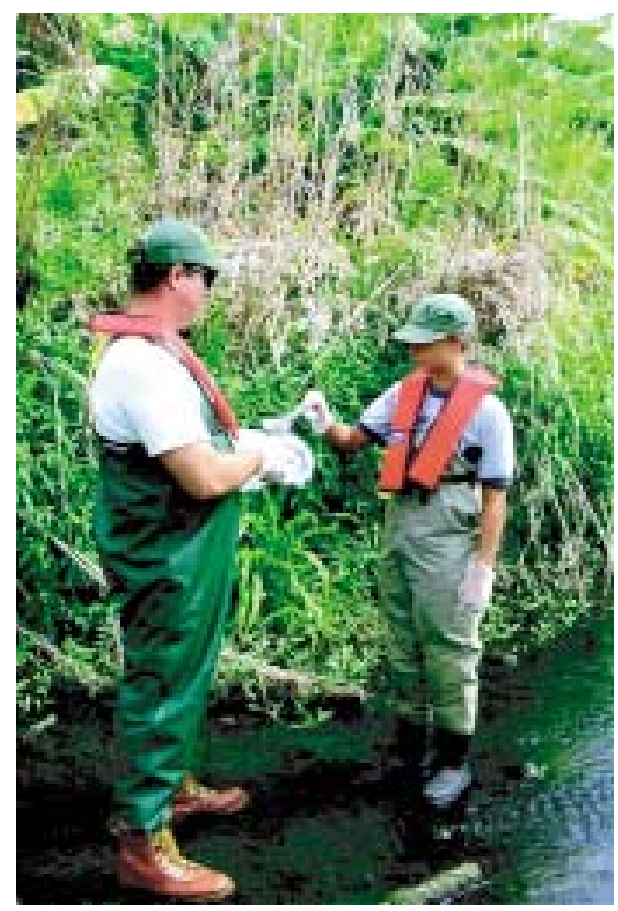

Collecting sediment samples.

at least 100 grams. Two samples of fish (two different Poeciliid species) were collected at two of the sites (Manoa and Kaneohe Streams) to see if there were differences in organochlorine concentrations between species.

\section{What are organochlorine pesticides, and why are they important?}

Organochlorine pesticides are chlorine-containing compounds which are found in the environment as the result of human activities. In the past, they were heavily used in agriculture and to control termites and mosquitoes. In the United States, the use of most organochlorine pesticides was

Table 1. Land-use characteristics and species selection at sampling sites $\left[\mathrm{mi}^{2}\right.$, square miles]

\begin{tabular}{|c|c|c|c|c|c|c|}
\hline Stream & Station number & Land use & $\begin{array}{l}\text { Population density } \\
\text { (persons per } \mathrm{mi}^{2} \text { ) }\end{array}$ & $\begin{array}{c}\text { Drainage area } \\
\qquad\left(\mathrm{mi}^{2}\right)\end{array}$ & \multicolumn{2}{|c|}{ Species sampled } \\
\hline Manoa & 16242500 & urban & 2,519 & 6 & $\begin{array}{l}\text { Gambusia affinis } \\
\text { Xiphophorus helleri }\end{array}$ & $\begin{array}{l}\text { mosquito fish } \\
\text { green swordtail }\end{array}$ \\
\hline Nuuanu & 16235100 & urban & 2,072 & 4.5 & Poecilia sphenops & molly \\
\hline Kaneohe & 16274100 & urban & 1,968 & 5.2 & $\begin{array}{l}\text { Poecilia sphenops } \\
\text { Gambusia affinis }\end{array}$ & $\begin{array}{l}\text { molly } \\
\text { mosquito fish }\end{array}$ \\
\hline Waikele & 16213000 & mixed & 1,168 & 46.2 & Xiphophorus helleri & green swordtail \\
\hline Poamoho & 213407158065801 & agriculture & 16 & 17.9 & Hemichromis elongatus & jewel cichlid \\
\hline Waihee & 16284200 & conservation & 0 & 0.9 & Xiphophorus helleri & green swordtail \\
\hline
\end{tabular}




\section{ORGANOCHLORINE PESTICIDES}

- Result from human activity; not naturally occurring

- Heavily used in the past in agriculture and for termite control

- Easily sorb to sediment and fatty tissue

- Are persistent (can last for decades)

- Have high potential to accumulate in fish and wildlife

- Affect reproductive viability

- Linked to endocrine disruption

discontinued in the 1970s for agriculture and in the 1980s for termite control.

The presence of persistent organochlorine pesticides in the environment may be related to both past and present land use in a watershed.

Organochlorine pesticides enter the aquatic environment from a variety of sources, including the atmosphere, industrial and municipal effluents, and agriculture and urban nonpoint-source runoff.

Organochlorine pesticides typically have low solubility and are commonly transported through soil erosion and surface runoff. They are mostly associated with bottom sediments, which can be ingested by benthic organisms. These organisms are then eaten by fish and birds, which can result in higher concentrations through aquatic and terrestrial food chains.

Many organochlorine pesticides are known animal carcinogens and are potential human carcinogens. The adverse effects of DDT on reproduction in birds has been well documented, and other organochlorine pesticides have been linked to endocrine disruption, an alteration of natural hormonal activity.

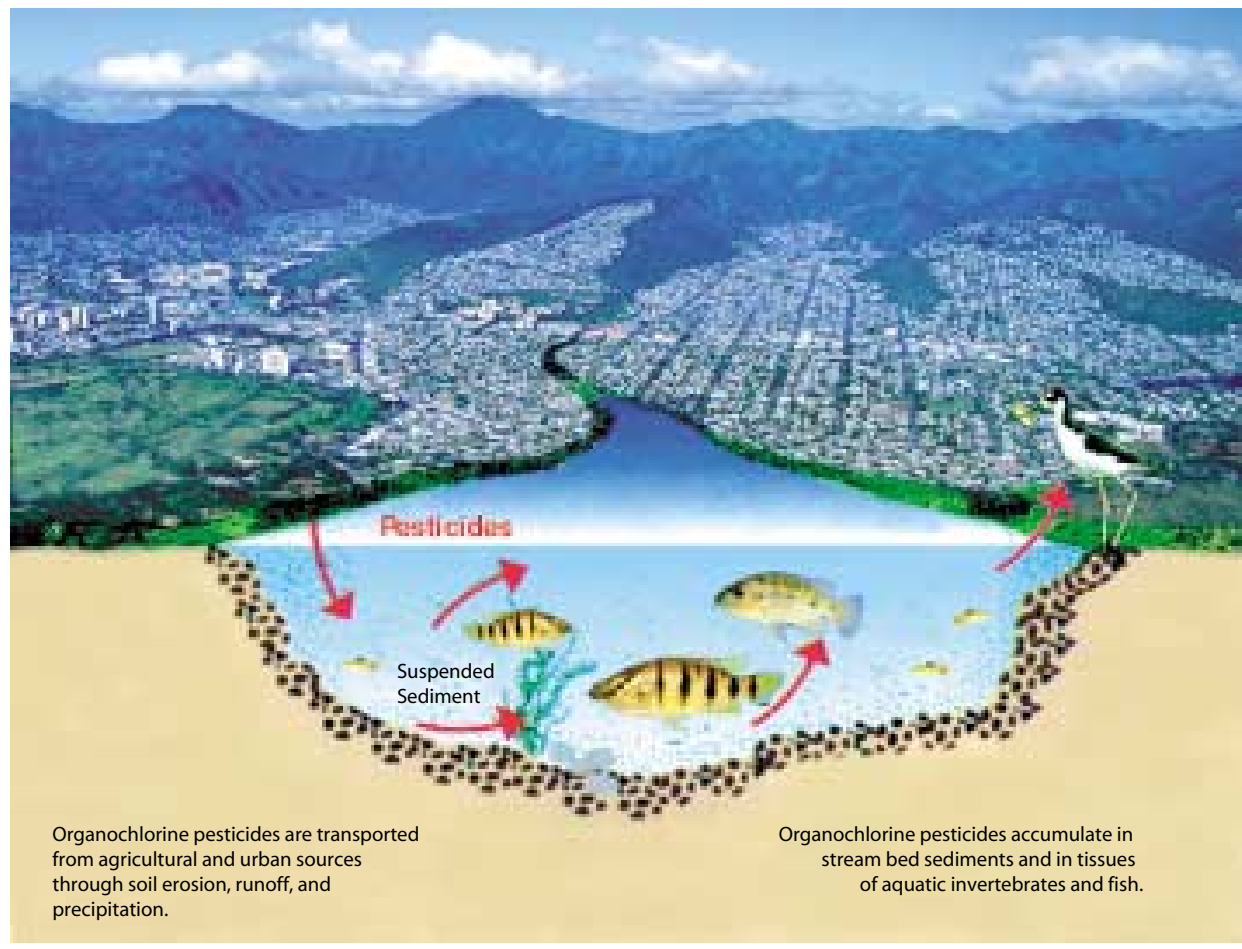

Organochlorine pesticides in the food chain.

\section{Why analyze sediment and tissue?}

Sediment serves as both a source and a removal mechanism for contaminants to and from the stream, and as a means of contaminant transport downstream. Sediment also provides habitat for benthic biota, and can be ingested by them. Aquatic biota are important in the food web around the stream, and some organisms such as fish are consumed by people and birds. Accumulation of contaminants can cause harm to the biota and to those who consume them.

Stream bed sediment and fish tissue contain higher concentrations of organochlorine compounds than the surrounding water, so analysis of sediment and tissue increases the likelihood of detecting compounds that are present in the stream.

\section{Evaluating potential effects}

Guidelines have been established for certain contaminants to help determine what concentrations of chemicals are likely to be associated with adverse biological effects. Concentrations found in Oahu stream bed sediments were compared with the Canadian Sediment Quality Guidelines (CSQG) for aquatic life
(Canadian Council of Ministers of the Environment, 1999). Concentrations found in fish tissue were compared with the NYSDEC (New York State Department of Environmental Conservation) guidelines for the protection of mammals and birds that consume fish (Newell and others, 1987).

Two assessment values have been calculated for the CSQG. The lower value or ISQG (interim sediment quality guidelines) represents the concentration below which adverse effects to aquatic biota are rarely

\section{LIMITATIONS OF GUIDELINES FOR EVALUATING EFFECTS}

- Established for only a limited number of pesticides

- Toxicity of mixtures and breakdown products not generally considered

- Some types of effects, such as endocrine disruption and unique responses of sensitive individuals, have not been assessed 


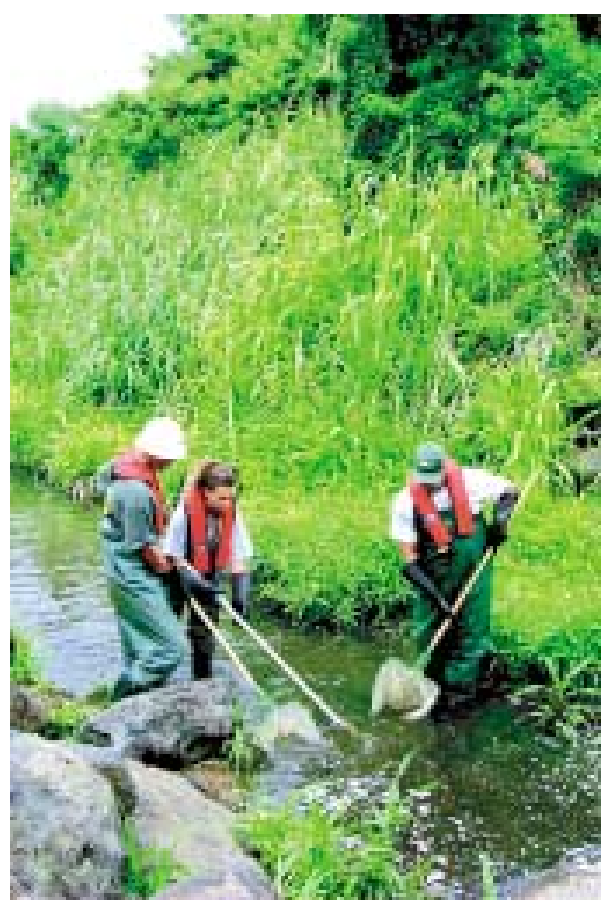

Collecting fish samples.

expected to occur. The upper value or PEL (probable effect level) defines the level above which adverse effects to aquatic biota are expected to occur frequently. These guidelines are based on chronic (long-term) effects of contaminants on aquatic organisms.

Results from the bed sediment and fish tissue survey indicate that high levels of organochlorine pesticides occur in sediment and fish tissue collected at urban and mixed land-use sites on the island of Oahu. Many of the contaminants detected exceeded guidelines for the protection of birds that eat fish and/or for aquatic life associated with stream bed sediments.

\section{Aldrin and dieldrin}

Aldrin was heavily used as a termiticide in urban areas on Oahu prior to 1984 . Approximately 9,000 pounds of aldrin was applied in Hawaii for pest control in 1977 (Pesticide Hazard Assessment Project, 1982). Once in the environment, aldrin is rapidly metabolized to dieldrin. Unlike in other areas of the country, dieldrin itself was not commonly used as a termiticide in Hawaii. The compound aldrin was detected in sediment, but not in fish tissue, at all three urban sites. Its degradation product, dieldrin, occurred at high concentration in both sediment and tissue at the urban sites. Dieldrin concentrations at the three urban sites exceeded the NYSDEC wildlife guideline $(120 \mu \mathrm{g} /$ $\mathrm{kg}$ ) for fish and the CSQG probable effect level $(6.67 \mu \mathrm{g} / \mathrm{kg})$ for sediment (fig. 2).

\section{Chlordane}

Although chlordane also has agricultural uses, its presence on Oahu is primarily associated with urban areas, notably as a termiticide. Chlordane and heptachlor were the most frequently applied termiticides, with Hawaii pest control use totaling 150,000 pounds in 1977 (Pesticide Hazard Assessment Project, 1982). Commercial use of chlordane was
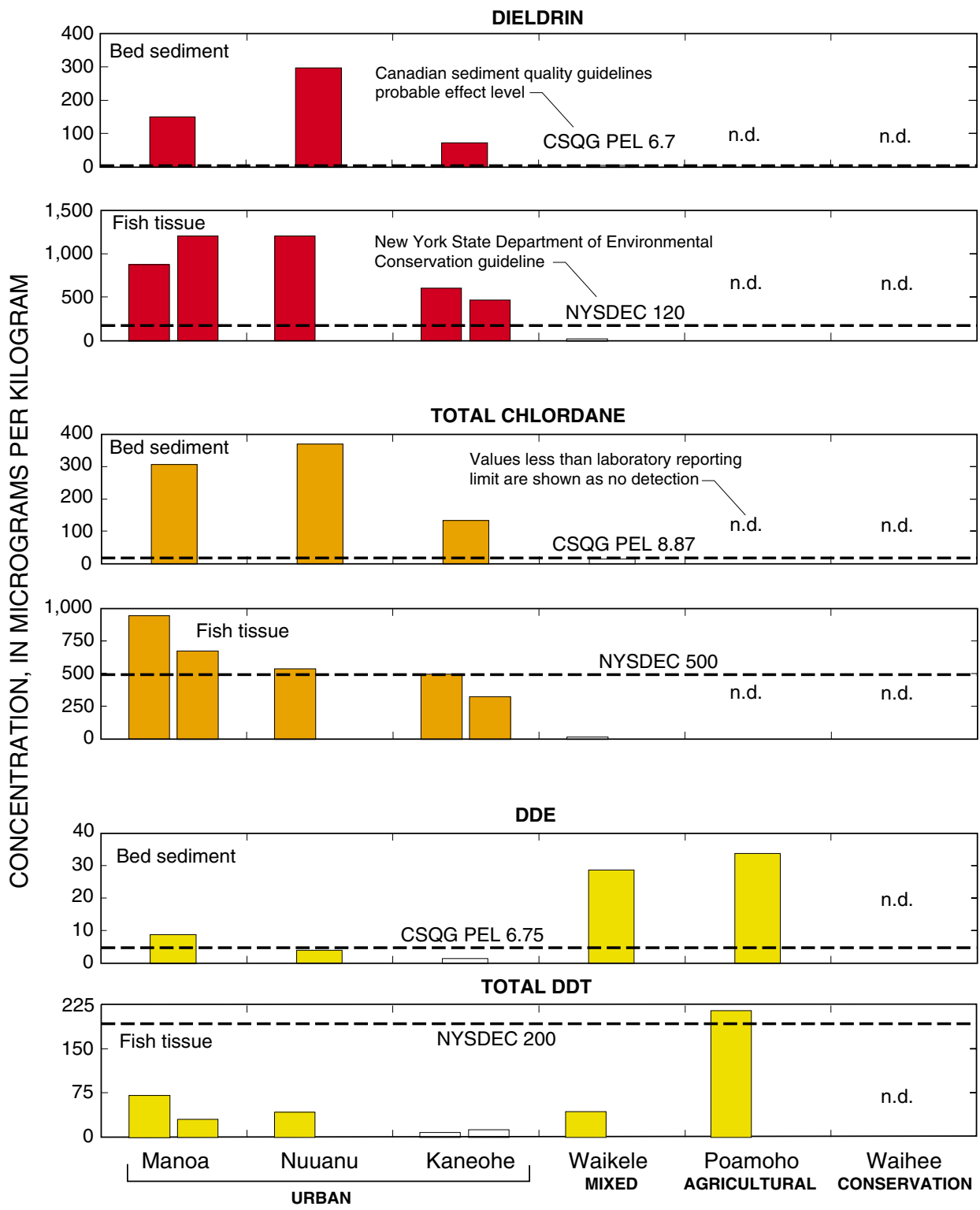

Figure 2. Dieldrin, chlordane, and DDT compounds in bed sediment and fish tissue at different land-use sites on Oahu. (All concentrations are actual values, not normalized to percent lipid or total organic carbon. Tissue values are wet weight. Sediment values are dry weight.) banned in 1988. Ten years later, some forms of chlordane are still detected at the urban and mixed (agriculture and urban) land-use sites (fig. 2).

At the urban sampling sites, total chlordane (the sum of cis- and transchlordane, cis- and trans-nonachlor, oxychlordane, and heptachlor expoxide) in fish tissue approached or exceeded the NYSDEC guidelines $(500 \mu \mathrm{g} / \mathrm{kg})$ for the protection of fisheating birds and mammals. At the three urban and the mixed land-use site, the CSQG guideline (probable effect level of $8.87 \mu \mathrm{g} / \mathrm{kg}$ ) for the protection of aquatic life was exceeded in stream sediment. 


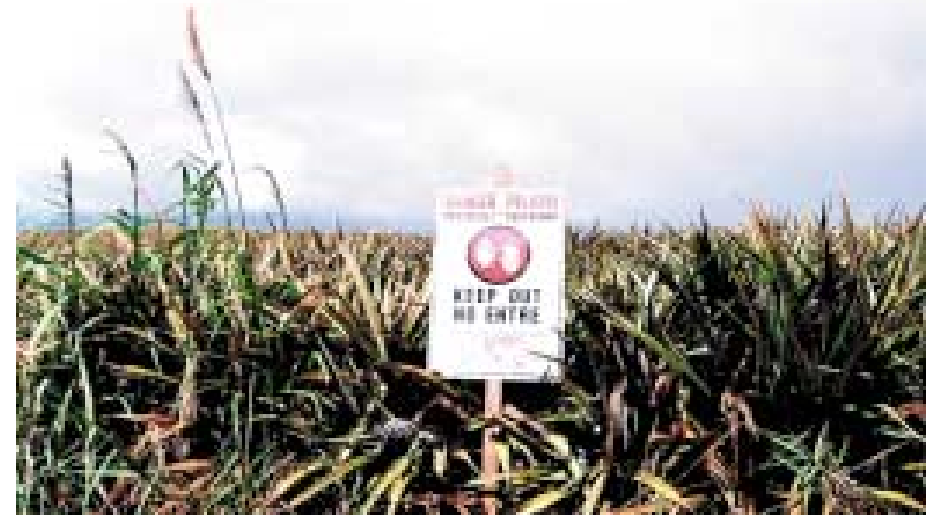

Agriculture is changing from single crop plantations, such as pineapple and sugarcane, to diversified crops.

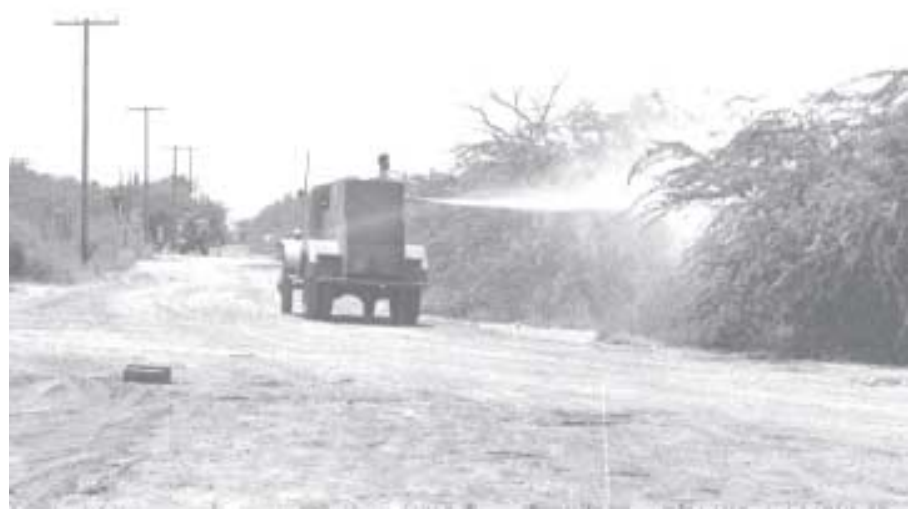

Spraying DDT for mosquito control in the late 1950s.

\section{DDT}

Use of the insecticide DDT began in 1939. DDT was broadly applied until its agricultural use was banned in the United States in 1972. DDT breaks down to DDE and DDD, which are also toxic and resistant to further chemical breakdown.

Some form of DDT was detected in both the sediment and fish tissue at all sampling sites on Oahu except for the reference site (fig. 2). The highest concentrations were found at the agricultural and mixed land-use sites.

Canada's guidelines for DDE in

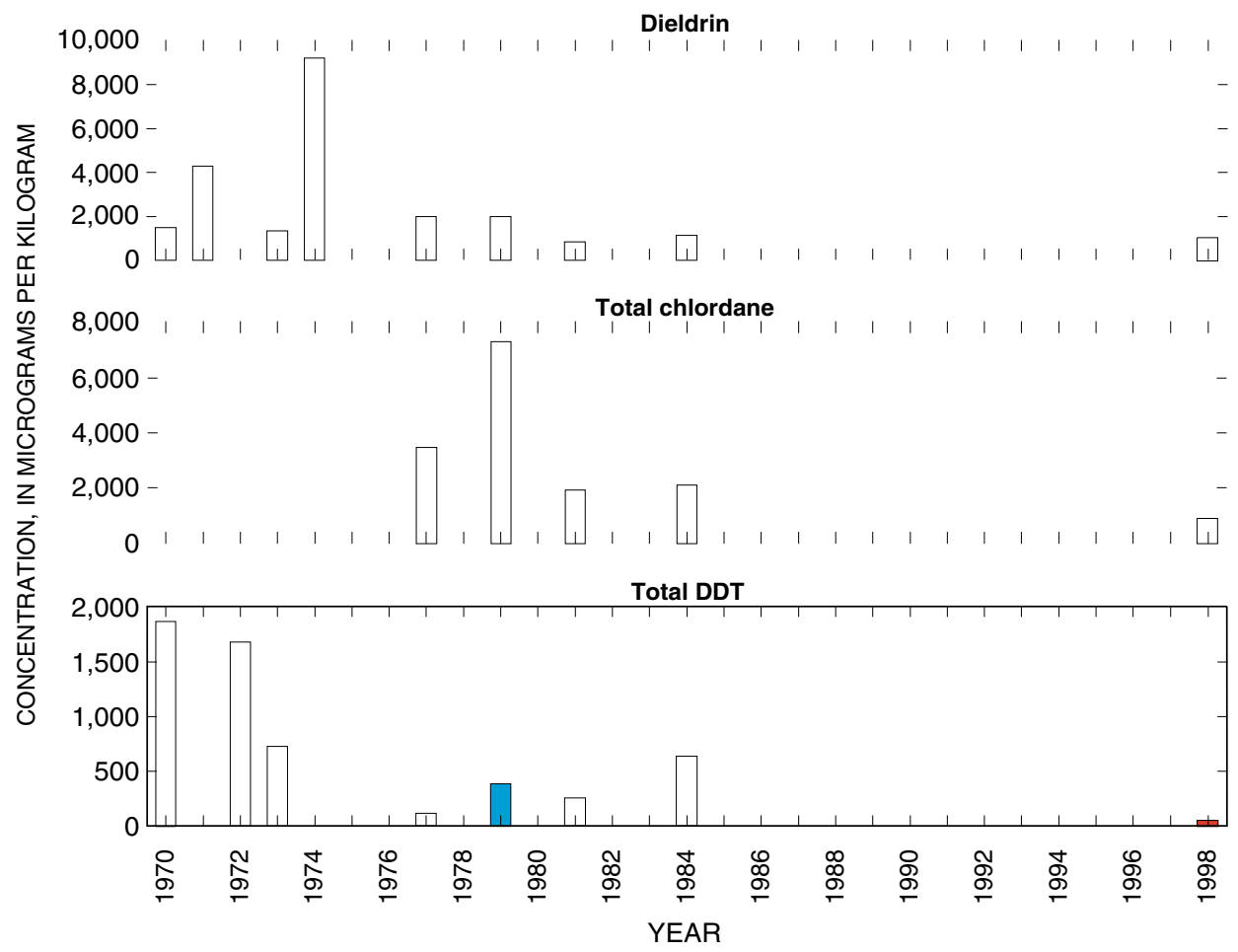

Figure 3. Selected organochlorine compounds detected in whole fish at Manoa Stream over time. Blue bars are U.S. Fish and Wildlife Service samples, red bars are Oahu NAWQA samples (mean of two samples). sediment (probable effect level of 6.75 $\mu \mathrm{g} / \mathrm{kg}$ ) was exceeded at three of the six sites. Total DDT (the sum of $o, p^{\prime}-$ DDT, $p, p^{\prime}-\mathrm{DDT}, o, p^{\prime}$-DDE, $p, p^{\prime}-\mathrm{DDE}$, $o, p^{\prime}$-DDD, and $p, p^{\prime}$-DDD) in the fish tissue exceeded the NYSDEC wildlife guideline $(200 \mu \mathrm{g} / \mathrm{kg})$ at Poamoho Stream, the agricultural site.

\section{Trends over time}

Concentrations of most organochlorine compounds in stream bed sediment and fish tissue across the Nation declined following the ban on their agricultural use in the early 1970s and Dieldrin then appeared to level off during the 1980s (Nowell and others, 1999). A similar trend occurred on Oahu, as shown (fig. 3) by a comparison of the 1998 NAWQA fish tissue samples from Manoa Stream with those collected from this stream by the U.S. Fish and Wildlife Service in the 1970s and early 1980s (Schmitt and others, 1981, 1980).

\section{National comparison}

While concentrations of organochlorine compounds in fish and sediment from Oahu streams have decreased since the 1970s, some remain high compared to other regions of the country. Results from data collected from 1992 through 1994 by NAWQA study units across the Nation indicate Oahu has levels of DDT in sediment and fish tissue comparable to other places, with concentrations measured at the agricultural site (Poamoho Stream) lower than at agricultural areas in other parts of the Nation. Levels of dieldrin and chlordane at the urban Oahu sites are much higher than those measured by other NAWQA study units (fig. 4).

\section{Summary and implications}

Organochlorine pesticides are transported from agricultural and urban sources primarily through soil erosion and surface runoff, and to a lesser extent, through ground water and atmospherically. Organochlorine pesticides, which accumulate in stream bed sediments and in tissues of 

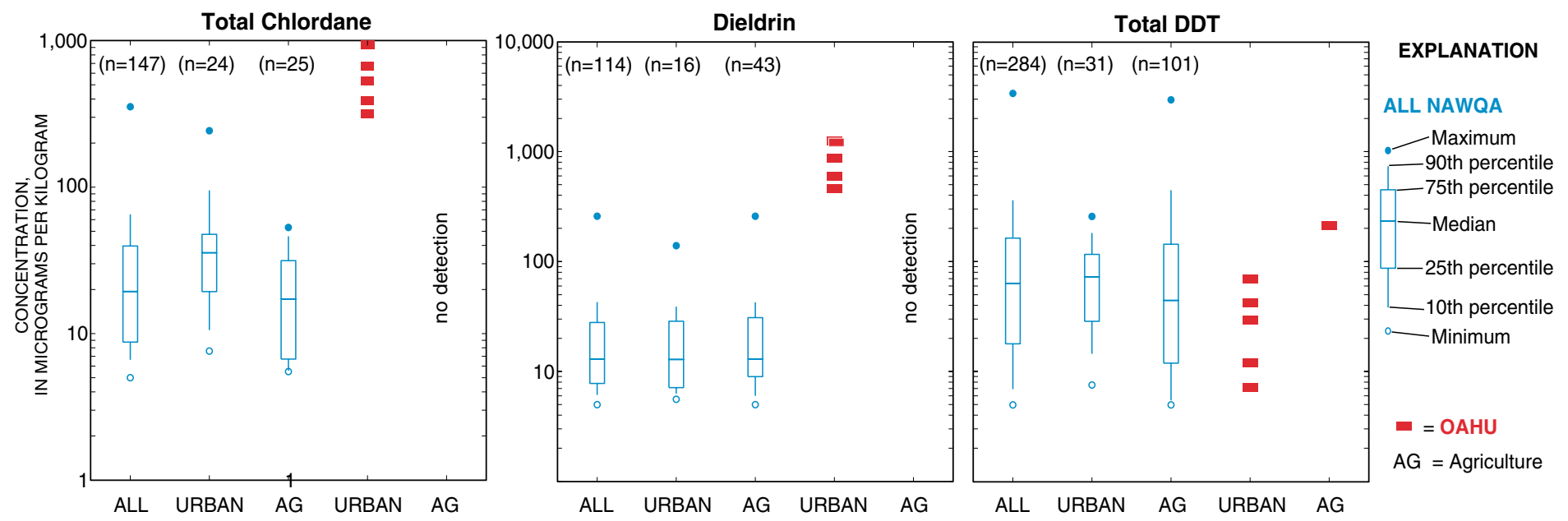

Figure 4. Range of concentrations of organochlorine compounds in fish collected by NAWQA study units across the Nation in 1992-94 and from Oahu NAWQA sites in 1998. (Data shown do not include non-detections.)

aquatic invertebrates and fish, continue to persist in aquatic ecosystems on the island of Oahu, even though most are no longer used here.

The distribution of organochlorine pesticides was associated with landuse practices including agriculture and urbanization. DDT and its related compounds were detected at all landuse sites except the forested reference site, but were highest at the agricultural site. Chlordane and dieldrin were found at high levels in all urban streams that were sampled.

Many organochlorine pesticides have been linked to hormone disruption and reproductive problems in aquatic invertebrates, fish, birds, and mammals (Kavlock and others, 1996). These effects, combined with a slow rate of breakdown, make many organochlorines a long-term environmental concern. Endangered native waterbirds, such as the Hawaiian Stilt (Himantopus mexicanus knudseni), which consume fish or aquatic invertebrates, may be at risk because concentrations of these compounds in both stream bed sediment and fish tissue in several Oahu streams exceeded guidelines for the protection of aquatic life and wildlife.

Agricultural and urban soils are sources of many organochlorine compounds to Oahu streams. Although little can be done about present concentrations in soils, controlling soil erosion (especially during clearing of land and construction in newly developed areas) could reduce the quantities of sediment entering streams, and ultimately, estuaries and nearshore marine systems. Monitoring all of these systems is needed to determine if concentrations are decreasing and whether soil-erosion reduction practices are effective.

\section{References Cited}

Canadian Council of Ministers of the Environment, 1999, Canadian sediment quality guidelines for the protection of aquatic life: Summary tables, in Canadian environmental quality guidelines, 1999: Canadian Council of Ministers of the Environment, Winnipeg, Canada (http:// www.ec.gc.ca/ceqg-rcqe).

Crawford, J.K. and Luoma, S.N., 1993, Guidelines for studies of contaminants in biological tissues for the National Water-Quality Assessment Program: U.S. Geological Survey Open-File Report 94-458, 69 p.

Kavlock, R.J., Daston, G.P., DeRosa, C., and others, 1996, Research needs for the risk assessment of health and environmental effects of endocrine disruptors: A report of the U.S. EPAsponsored workshop, Environmental Health Perspectives, vol. 104, Supplement 4, p. 715-739.

Newell, A.J., Johnson, D.W., and Allen, L.K., 1987, Niagra River biota contamination project: Fish flesh criteria for piscivorous wildlife: New York State Department of Environmental Conservation, Division of Fish and Wildlife, Bureau of Environmental Protection Technical Report 87-3, $182 \mathrm{p}$.
Nowell, L.H., Capel, P.D., and Dileanis, P.D., 1999, Pesticides in stream sediment and aquatic biota-Distribution, trends, and governing factors: Boca Raton, Fla., CRC Press, Pesticides in the Hydrologic System series, vol. 4, 1040 p.

Pesticide Hazard Assessment Project, 1982, Pesticide usage patterns in Hawaii, 1977: Pacific Biomedical Research Center, University of Hawaii, $92 \mathrm{p}$.

Shelton, L.R. and Capel, P.D., 1994, Guidelines for collecting and processing samples of streambed sediment for analysis of trace elements and organic compounds for the National WaterQuality Assessment Program: U.S. Geological Survey Open-File Report 94-458, $20 \mathrm{p}$.

Schmitt, C.J., Ludke, J.L., and Walsh, D.F., 1981, Organochlorine residues in fish: National Pesticide Monitoring Program, 1970-1974: Journal of Pesticide Monitoring, no. 4, p. 136206.

Schmitt, C.J., Zajicek, J.L., and Paterman, P.H., 1980, National Contaminant Biomonitoring Program: Residues of organochlorine chemicals in freshwater fish, 1976-1984: Archives of Environmental Contamination and Toxicology, vol. 19 , no. 5, p. 748-781.

Information on technical reports and
hydrologic data related to the Oahu NAWQA
program can be obtained from:
Stephen S. Anthony
Oahu NAWQA Chief
U. S. Geological Survey
677 Ala Moana Blvd. Suite 415
Honolulu, HI 96813
(808) 587-2406
http://hi.water.usgs.gov/
$\begin{aligned} & \text { Background photo used on cover banner and organochlorine diagram } \\ & \text { by Douglas Peebles }\end{aligned}$
$2000 \quad$ Fact Sheet 140-00

